\title{
P239: Salmonella group B 4,5 outbreak on a neonatology unit
}

\author{
M Grande, P Rodríguez*, M Terol, M Triviño, C Suárez, C Gil \\ From 2nd International Conference on Prevention and Infection Control (ICPIC 2013) \\ Geneva, Switzerland. 25-28 June 2013
}

\section{Introduction}

We report an outbreak of Salmonella group B 4,5 infections in patients on a Neonatology unit, and describe the epidemiological investigations and control measures undertaken.

\section{Methods}

After identification of various Salmonella group B 4,5 positive cultures from different patients staying in the Neonatology Unit, active surveillance through clinical and microbiological results was initiated.

Stool cultures were taken from all patients admitted to the unit and screening of medical staff for healthy carriers was performed.

We studied the compliance of specific precautions based on contact transmission among the personnel working in the unit but also among consulted professionals from other departments.

\section{Results}

After the vertical transmission of Salmonella group B 4,5 in two twins born in the hospital in May 2012, both admitted to the neonatology unit with a diagnosis of sepsis, during the month of June four more patients were identified with Salmonella group B 4,5-positive cultures, of whom one presented sepsis, one suffered from gastroenteritis and two patients remained asymptomatic. In the following day all six patients were discharged, four of them still colonized with Salmonella group B4,5.

In June 2012 all stool cultures of patients admitted to the Neonatology Unit were negative. No carriers were detected among healthcare staff.

Hand hygiene compliance in the unit was $76,8 \%$.

\footnotetext{
Preventive Medicine and Quality Management, General University Hospital
} Gregorio Marañón. Madrid. Spain

C 2013 Grande et al; licensee BioMed Central Ltd. This is an Open Access article distributed under the terms of the Creative Commons Attribution License (http://creativecommons.org/licenses/by/2.0), which permits unrestricted use, distribution, and reproduction in any medium, provided the original work is properly cited.
Possible areas of improvement were found to be hand hygiene in consulted professionals from other departments as well as the cleaning of machines and devices (monitors, ultrasound machine) after using them.

\section{Conclusion}

Data suggested that the source of the infection was the index patient's mother who was colonized with Salmonella group B 4,5; the mode of transmission was most likely due to the transfer of organisms from infant to infant by cross transmission.

\section{Disclosure of interest}

None declared.

Published: 20 June 2013

doi:10.1186/2047-2994-2-S1-P239

Cite this article as: Grande et al:: P239: Salmonella group B 4,5 outbreak on a neonatology unit. Antimicrobial Resistance and Infection Control 2013 2(Suppl 1):P239.

Submit your next manuscript to BioMed Central and take full advantage of:

- Convenient online submission

- No space constraints or color figure charges

- Immediate publication on acceptance

- Inclusion in PubMed, CAS, Scopus and Google Scholar

- Research which is freely available for redistribution Submit your manuscript at
www.biomedcentral.com/submit C BioMed Central
- Thorough peer review
C Biomed Central 